\title{
Identification of Putative Parasitism Genes Expressed in the Esophageal Gland Cells of the Soybean Cyst Nematode Heterodera glycines
}

\author{
Bingli Gao, ${ }^{1}$ R. Allen, ${ }^{1}$ Tom Maier, ${ }^{2}$ Eric L. Davis, ${ }^{3}$ Thomas J. Baum, ${ }^{2}$ and Richard S. Hussey ${ }^{1}$ \\ ${ }^{1}$ Department of Plant Pathology, University of Georgia, Athens 30602-7274, U.S.A.; ${ }^{2}$ Department of Plant \\ Pathology, lowa State University, 351 Bessey Hall, Ames 50011, U.S.A.; ' ${ }^{3}$ Department of Plant Pathology, \\ North Carolina State University, Box 7616, Raleigh 27695-7616, U.S.A. \\ Submitted 21 March 2001; Accepted 26 June 2001.
}

\begin{abstract}
Cloning parasitism genes encoding secretory proteins expressed in the esophageal gland cells is the key to understanding the molecular basis of nematode parasitism of plants. Suppression subtractive hybridization (SSH) with the microaspirated contents from Heterodera glycines esophageal gland cells and intestinal region was used to isolate genes expressed preferentially in the gland cells of parasitic stages. Twenty-three unique cDNA sequences from a SSH cDNA library were identified and hybridized to the genomic DNA of $\mathrm{H}$. glycines in Southern blots. Fulllength cDNAs of 21 clones were obtained by screening a gland-cell long-distance polymerase chain reaction cDNA library. Deduced proteins of 10 clones were preceded by a signal peptide for secretion, and PSORT II computer analysis predicted eight proteins as extracellular, one as nuclear, and one as plasmalemma localized. In situ hybridization showed that four of the predicted extracellular clones were expressed specifically in the dorsal gland cell, one in the subventral gland cells, and three in the intestine in $H$. glycines. The predicted nuclear clone and the plasmalemma-localized clone were expressed in the subventral gland cells and the dorsal gland cell, respectively. SSH is an efficient method for cloning putative parasitism genes encoding esophageal gland cell secretory proteins that may have a role in $\boldsymbol{H}$. glycines parasitism of soybean.
\end{abstract}

Additional keywords: macroarray, plant-parasitic nematode, sedentary plant parasites, stylet secretions.

Plant-parasitic nematodes in the orders Tylenchida and Aphelenchida possess three large, transcriptionally active esophageal gland cells, one dorsal and two subventral, that are the principal sources of secretions involved in nematode infection and parasitism of plants. Sedentary endoparasitic nematodes, which are the most economically important plant parasitic nematodes, synthesize secretory proteins in their esophageal gland cells and release these proteins through a hollow, protrusible stylet during migration within plant roots and sub-

Corresponding author: R. S. Hussey; Telephone: +1-706-542-1254; Fax: +1-706-542-1262; E-mail: hussey@ arches.uga.edu

Nucleotide and/or amino acid sequence data are available in the DDBJ/ EMBL/GenBank databases. Accession numbers are listed in Table 1. sequent modification of root cells into discrete feeding cells (Hussey and Grundler 1998). The two subventral gland cells are the most active gland cells in infective second-stage juveniles, whereas the single dorsal gland cell becomes the predominate source of secretions released through the stylet in subsequent parasitic stages of sedentary endoparasites (Hussey 1989). Research on nematode stylet secretions has been hindered greatly by the minute quantities of secretions available from these small biotrophs. Therefore, cloning parasitism genes encoding proteins secreted from the esophageal gland cells and injected through the stylet into plant tissue is the key to understanding the molecular basis of nematode parasitism of plants.

The nature of a few nematode esophageal gland secretory proteins and their function in parasitism is beginning to emerge (Davis et al. 2000). The first parasitism genes encoding esophageal gland cell secretory proteins to be cloned from plant-parasitic nematodes were subventral gland cell-specific $\beta$-1,4-endoglucanases (cellulases) from cyst nematodes (Smant et al. 1998; Yan et al. 1998). Cellulases are synthesized in the subventral gland cells of Globodera rostochiensis and Heterodera glycines and secreted within host tissue by infective juveniles during the intracellular migration phase of the infection process (Wang et al. 1999). Cellulase genes expressed in the subventral gland cells also have been cloned from Meloidogyne incognita (Rosso et al. 1999) and Globodera tabacum (Goellner et al. 2000). cDNA encoding (pel-1) a pectate lyase has been cloned from $G$. rostochiensis (Popeijus et al. 2000). Other putative parasitism genes have been cloned and characterized, but the function of their secretory products in nematode parasitism of plants remains unknown (Davis et al. 2000).

Several molecular approaches have been used recently to clone secretion genes expressed in the esophageal gland cells of plant-parasitic nematodes. Differential screening to identify genes expressed in the anterior gland region versus posterior of a nematode or between preparasitic and parasitic stages has resulted in the cloning of two putative parasitism genes expressed in root-knot nematode gland cells (Ding et al. 1998; Lambert et al. 1999). A cDNA-amplified fragment length polymorphism analysis of different life stages of $G$. rostochiensis yielded three putative parasitism genes, which are expressed in the dorsal gland cell (Qin et al. 2000). Recently, a 
more direct approach involving microaspiration of gland cell cytoplasm and a eukaryotic secretion signal peptide cDNA selection system was used to clone four secretion genes expressed in the dorsal gland cell of parasitic stages of $H$. glycines (Wang et al. 2001). Even with these recent successes in cloning putative nematode parasitism genes, however, a more efficient selection system is desirable to obtain a complete profile of the parasitism genes expressed in the nematode esophageal gland cells during the parasitic cycle. In our study, we combined the direct method of microaspiration of cytoplasm of the esophageal gland cells to provide expressed mRNA for reverse-transcription-polymerase chain reaction (RT-PCR) with suppression subtractive hybridization (SSH) using cDNAs generated from contents microaspirated from the intestinal region of $H$. glycines to generate a library enriched with esophageal gland cell secretory protein cDNAs. cDNAs encoding secretory proteins were identified by macroarraying the $\mathrm{SSH}$ products onto nylon membranes and high-throughput in situ screening of selected clones in $H$. glycines specimens. New putative parasitism genes expressed in the esophageal gland cells were rapidly identified, and their full-length clones were obtained from a gland-cell long-distance (LD) PCR cDNA library generated from the same esophageal gland cell cytoplasm.

\section{RESULTS}

\section{LD PCR gland-cell library construction.}

Template mRNA from $10 \mathrm{H}$. glycines gland cells was purified with oligo $(\mathrm{dT})_{25}$ magnetic beads for RT-PCR. Because overcycling may yield nonspecific PCR products, in preliminary experiments $15,18,21,24,27,30$, and 33 PCR cycles were carried out to determine the fewest cycles needed to obtain the best, or specific, cDNAs as well as a low-redundancy, LD PCR product to create a LD PCR cDNA library. To save the template, 10 out of $100 \mu$ of firststrand gland-cell cDNA was used in a $100-\mu$ l volume of LD PCR reaction, and cycles were continued by placing the reaction back in the thermal cycler for three additional cycles. The optimum number of LD PCR cycles (24) was determined by comparing patterns of $10 \mu \mathrm{l}$ of a PCR product on $1 \%$ agarose gel.

An aliquot of the LD PCR product was used to create the gland-cell LD PCR cDNA library. This approach enabled full-length clones of any cDNA identified in the gland-cell SSH cDNA library to be obtained easily. Gel analysis of 20 clones selected randomly from the glandcell LD PCR cDNA library showed that inserts were 0.6 to $3.0 \mathrm{~kb}$.

Table 1. Summary of 23 unique cDNA clones from Heterodera glycines isolated by suppression subtractive hybridization

\begin{tabular}{|c|c|c|c|c|c|c|c|c|}
\hline Clone & $\begin{array}{l}\text { Accession } \\
\text { no. }^{\mathrm{a}}\end{array}$ & $\begin{array}{l}\text { SSH/FL } \\
(\text { (bp) })^{\mathbf{b}}\end{array}$ & Highest homology & $\begin{array}{c}\text { BLASTP } \\
\text { score/E value }\end{array}$ & $\begin{array}{c}\text { Signal } \\
\text { peptide }^{c}\end{array}$ & $\begin{array}{l}\text { DNA } \\
\text { blot }^{d}\end{array}$ & In situ ${ }^{\mathrm{e}}$ & PSORT II \\
\hline GSB9 & AF343567 & $495 / 850$ & $\begin{array}{l}\text { Hypothetical protein } \\
\text { Caenorhabditis elegans }\end{array}$ & $131 / 9 \mathrm{e}^{-30}$ & Y & 2 & SvG & Extracellular \\
\hline GSB 10 & AF344866 & $850 / 3,000+$ & Allergen ABA-1 Ascaris suum & $153 / 5 \mathrm{e}^{-36}$ & ND & 1 & NS & ND \\
\hline GSB23 & AF 273728 & $430 / 620$ & $\begin{array}{l}\text { Gland cell secretory protein } H \text {. } \\
\text { glycines }\end{array}$ & $182 / 8 \mathrm{e}^{-3}$ & $\mathrm{Y}$ & 5 & DG & Extracellular \\
\hline GSB6 & AF344868 & $447 / 1,500$ & Hypothetical protein C. elegans & $105 / 2 \mathrm{e}^{-35}$ & $\mathrm{Y}$ & 3 & NS & Extracellular \\
\hline GSB21 & AF345801 & $437 / 630$ & Pioneer $^{\mathrm{g}}$ & & $\mathrm{Y}$ & 1 & DG & Plasma membrane \\
\hline GSB3 & AF345800 & $487 / 1,760$ & Pioneer & & $\mathrm{Y}$ & 4 & SvG & Nuclear \\
\hline GSB 17 & AF345802 & $307 / 2,400$ & $\begin{array}{l}\text { Endoplasmic reticulum ATPase } \\
\text { C. elegans }\end{array}$ & $52 / 3 \mathrm{e}^{-06}$ & $\mathrm{~N}$ & 2 & NS & Cytoplasmic \\
\hline GSB 15 & AF345794 & 486/ND & Dynein heavy chain $C$. elegans & $197 / 8 \mathrm{e}^{-50}$ & $\mathrm{~N}$ & 1 & NS & Cytoplasmic \\
\hline GSB13 & AF345798 & $224 / 1,100$ & Pioneer & & $\mathrm{N}$ & 3 & NS & Nuclear \\
\hline GSB18 & AF345799 & $166 / 760$ & Pioneer & & $\mathrm{N}$ & 1 & NS & Nuclear \\
\hline GSB24 & AF344862 & $383 / 1,510$ & $\begin{array}{l}\text { Salivary proline-rich } \\
\text { glycoprotein Rattus norvegicus }\end{array}$ & $86 / 5 \mathrm{e}^{-16}$ & $\mathrm{Y}$ & 1 & DG & Extracellular \\
\hline GSB25 & AF345793 & $383 / 1,930$ & Hypothetical protein $C$. elegans & $172 / 4 \mathrm{e}^{-48}$ & $\mathrm{~N}$ & 1 & NS & Cytoplasmic \\
\hline GSB26 & AF344864 & $174 / 1,320$ & Hypothetical protein C. elegans & $168 / 1 \mathrm{e}^{-55}$ & $\mathrm{~N}$ & & NS & Cytoplasmic \\
\hline SB59 & Y09499 & $184 / 1,100$ & $\begin{array}{l}\text { Cathepsin S-like cysteine } \\
\text { proteinase } H \text {. glycines }\end{array}$ & $126 / 3 \mathrm{e}^{-29}$ & $\mathrm{Y}$ & 2 & INT & Extracellular \\
\hline SB91 & AF345792 & $491 / 1,380$ & Cysteine proteinase $C$. elegans & $82 / 5 \mathrm{e}^{-15}$ & $\mathrm{Y}$ & 3 & INT & Extracellular \\
\hline SB4 & AF344867 & $778 / 1,384$ & $\begin{array}{l}\text { Aspartic protease Necator } \\
\text { americanus }\end{array}$ & $289 / \mathrm{e}^{-105}$ & $\mathrm{Y}$ & 1 & INT & Extracellular \\
\hline SB89 & AF344863 & $272 / 750$ & Pioneer & & $\mathrm{Y}$ & 3 & DG & Extracellular \\
\hline SB76 & AF344869 & $279 / 730$ & Histone Emericella nidulans & $92 / 3 \mathrm{e}^{-18}$ & $\mathrm{~N}$ & 3 & DG & Cytoplasmic \\
\hline SB26 & AF344870 & $264 / 1,200$ & Pioneer & & $\mathrm{N}$ & 2 & DG & Cytoplasmic \\
\hline SB84 & AF344865 & $370 / 3,000$ & Pioneer & & $\mathrm{N}$ & 1 & DG & Cytoplasmic \\
\hline SB93 & AF345795 & $296 / 900$ & Hypothetical protein C. elegans & $132 / 6 \mathrm{e}^{-30}$ & $\mathrm{~N}$ & 1 & NS & Cytoplasmic \\
\hline SB61 & AF345796 & $258 / 1,500$ & Hypothetical protein C. elegans & $132 / 8 \mathrm{e}^{-31}$ & $\mathrm{~N}$ & 2 & NS & Cytoplasmic \\
\hline SB3 & AF345797 & $446 / 1,200$ & $\begin{array}{l}\text { Pyruvate dehydrogenase } C \text {. } \\
\text { elegans }\end{array}$ & $138 / 3 \mathrm{e}^{-32}$ & $\mathrm{~N}$ & 1 & NS & Mitochondria \\
\hline
\end{tabular}

\footnotetext{
${ }^{a}$ New sequences submitted to DDBJ/EMBL/GenBank, with the exception of AF273728 and Y09499, which were already in the database.

${ }^{\mathrm{b}}$ Size of the cDNA insert in suppression subtractive hybridization (SSH) and full-length (FL) clones. ND $=$ not determined.

${ }^{c}$ Presence of a signal peptide predicted by computer analysis (Nielsen et al. 1997). Y = yes, $\mathrm{N}=$ no.

d Number of hybridization bands in Southern blot analysis with EcoRI-digested genomic DNA from H. glycines.

e In-situ hybridization of cDNA probes to mRNA specifically within the $H$. glycines dorsal esophageal gland cell (DG), subventral esophageal gland cells (SvG), or intestine (INT) or nonspecific binding (NS).

f Subcellular localization as predicted by PSORT II computer analysis (Nakai and Horton 1999).

g Novel transcript with no homology to any genes in the public databases.
} 


\section{Suppression subtraction hybridization and SSH cDNA library.}

We utilized a $\mathrm{SSH}$ protocol to subtract so-called driver cDNAs from tester cDNAs in order to obtain those cDNAs unique to the tester cDNA population. In these experiments, we subtracted intestinal region (driver) cDNAs from glandcell (tester) cDNAs. In addition to enriching the cDNAs in the tester sample, these subtractions also were performed to remove any cDNAs from potential bacterial contamination, which would have been present in both samples, i.e., glandcell cytoplasm and intestinal region cDNAs. The subtracted product was used to construct a cDNA library (referred to as the SSH cDNA library). Twenty clones from the SSH cDNA library picked randomly for cDNA insert-size confirmation showed that insert length was 200 to $800 \mathrm{bp}$.

\section{Screening the SSH cDNA library.}

The SSH gland-cell cDNA library was applied to nylon membranes to produce macroarray membranes to screen the cDNAs (Table 1). Initially, 20 random clones were assessed by in situ hybridization in $H$. glycines sections. These clones were then used as probes to hybridize to the macroarray membranes. Twenty additional cDNAs from the membranes that did not hybridize were selected for in situ hybridization. This direct screening of the SSH cDNA library by in situ hybridization identified 13 unique clones, of which five gave a specific hybridization signal within the esophageal gland cells of $H$. glycines (Table 1). Probes of GSB3 and GSB9 hybridized exclusively with the subventral gland cells (Fig. 1) and probes of GSB23, GSB21, and GSB24 hybridized specifically within the dorsal gland cell (Fig. 2). The hybridization signal was consistently weak in the dorsal gland cell of preparasitic second-stage juveniles and strong in the dorsal gland cell in the parasitic second-stage juveniles and later parasitic stages (Fig. 2 ). Because randomly cutting the nematodes for in situ localization usually precluded identifying the specific developmental stage in which the hybridization occurred, we scored the developmental expression of the genes based on three categories: preparasitic second-stage juveniles, parasitic second-stage juveniles, and later parasitic stages (third- and fourth-stage juveniles and young females). A nonspecific hybridization signal was observed within the $H$. glycines sections for the antisense probes of eight clones: GSB6, GSB10, GSB13, GSB15, GSB17, GSB18, GSB25, and GSB26.

For the final screening of the SSH cDNA library, the remaining clones (100), which had not hybridized with probes of pooled cDNAs that already had been sequenced, were selected for sequencing. These new sequences were then tested by in situ hybridization. This sequence analysis identified 10 additional unique clones (Table 1) and, in subsequent in situ hybridization, four DIG-labeled antisense cDNA probes (SB26, SB76, SB84, and SB89) gave specific hybridization signals within the dorsal gland cell of the preparasitic and parasitic stages of $H$. glycines. For all probes, the hybridization signal was consistently strongest in the parasitic stages (Fig. 3). The probes of three clones (SB4, SB59, and SB91) hybridized exclusively within the intestinal cells of the parasitic stages (Fig. 4). Antisense probes of three clones (SB3, SB61, and SB93) exhibited nonspecific hybridization within specimens of $H$. glycines (data not shown). No hybridization was observed within sections of $H$. glycines with the control sense cDNA probes of all clones.
In Southern blot hybridization at high stringency, all 23 cDNAs hybridized with genomic DNA from $H$. glycines (Table 1), and none hybridized with genomic DNA from $M$. incognita, Caenorhabditis elegans, soybean, or tomato (data not shown).

Full-length clones and predicted subcellular localization.

Probes of 22 (GSB15 excluded) of the unique cDNA clones identified from the SSH cDNA library screening were used to screen the gland-cell LD PCR cDNA library macroarray membranes. Full-length cDNAs were identified for 21 clones from .62 to $3.0 \mathrm{~kb}$ (Table 1). A large (approximately $3.0 \mathrm{~kb}$ ) but not full-length cDNA (lacking the $5^{\prime}$ end) was obtained for GSB10. The sequence of the predicted proteins encoded by these 21 full-length cDNAs were analyzed by BLASTP for similarity to known proteins, Signal P (Nielsen et al. 1997) for the presence of signal peptides, and PSORT II (Nakai and Horton 1999) to predict subcellular localizations. The presence of a signal peptide identifies a putative secretory protein that may have a role in plant pathogenesis, and 10 of the predicted proteins were preceded by a signal peptide (Table 1). PSORT II analyses predicted eight (GSB6, GSB9, GSB23, GSB24, SB4, SB59, SB89, and SB91) of the proteins, with a signal peptide to be extracellular, one (GSB21) to be a plasma membrane protein, and one (GSB3) to be localized nuclearly (Ta-
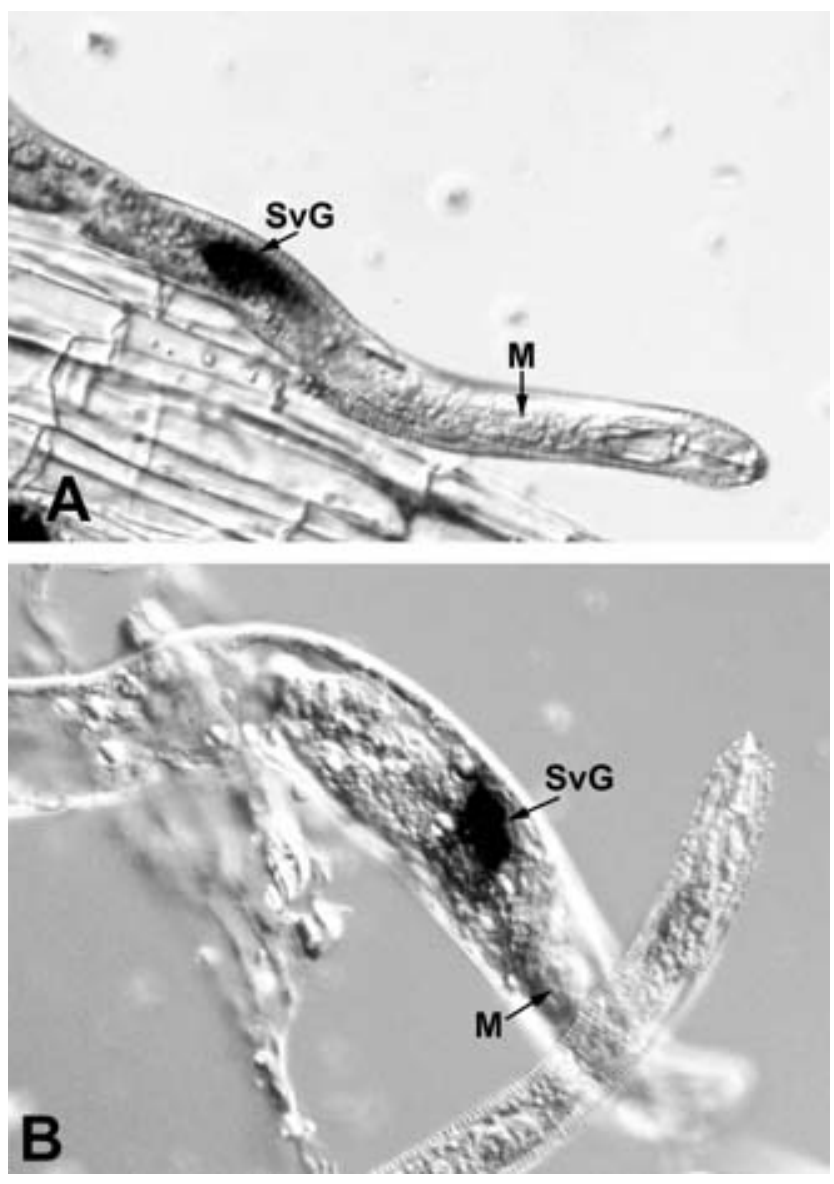

Fig. 1. Hybridization of a digoxigenin-labeled antisense cDNA probe (dark staining) of clone GSB9 (Table 1) to transcripts expressed exclusively within the subventral esophageal gland cells of Heterodera glycines. A, Parasitic second-stage juvenile. B, Late parasitic stage. SvG, subventral gland cells; M, metacorpus. 

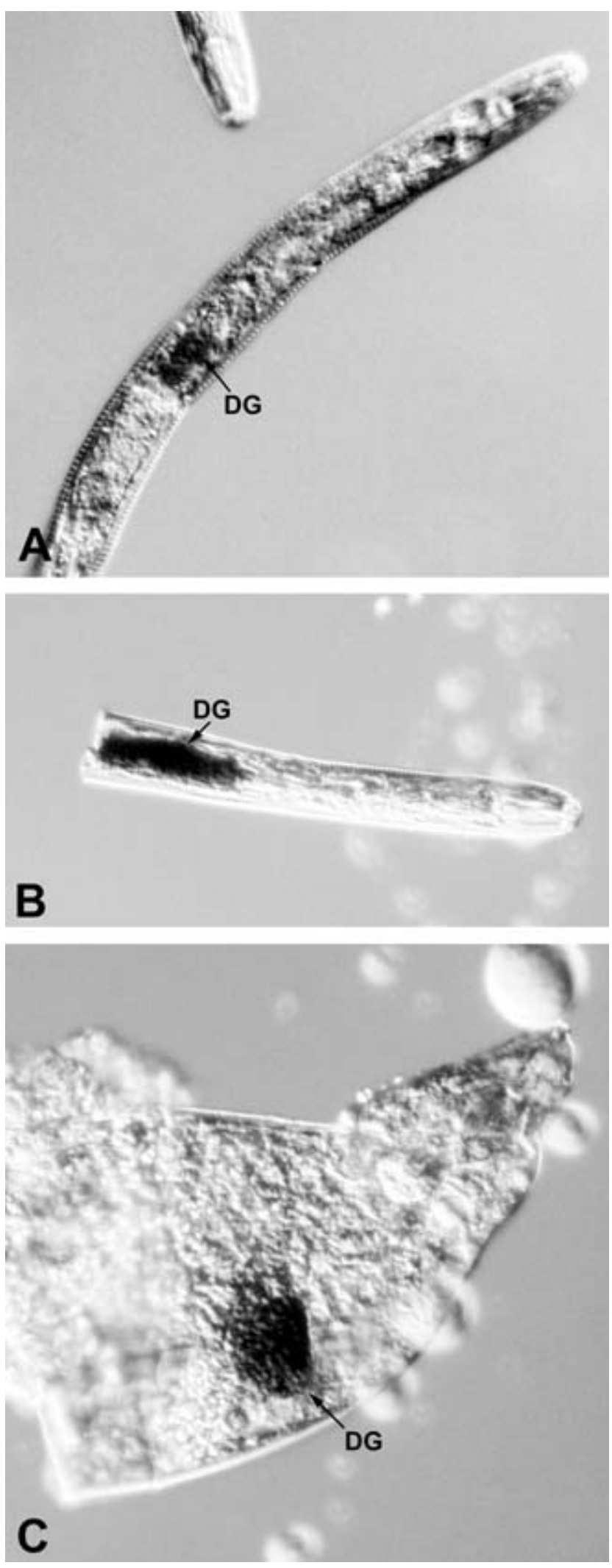

Fig. 2. Hybridization of a digoxigenin-labeled antisense cDNA probe (dark staining) of clone GSB24 (Table 1) to transcripts expressed exclusively within the dorsal esophageal gland cell of Heterodera glycines. A, Preparasitic second-stage juvenile. B, Parasitic second-stage juvenile. C, Late parasitic stage. DG, dorsal gland cell; M, metacorpus. ble 1). Although the $5^{\prime}$ end of GSB10 (3 kb) was not obtained, precluding prediction of its subcellular localization, homologous proteins are known to be extracellular (Tweedie et al. 1993). Seven of the predicted extracellular peptides had homology with known proteins on the basis of BLASTP analysis. Only SB89 lacked homology with any known protein. The protein encoded by GSB9 had the highest similarity with a hypothetical protein from $C$. elegans. GSB10, although not full length, was similar to antigen ABA-1 from Ascaris suum and a surface-associated glycoprotein from Brugia pahangi (Tweedie et al. 1993). The protein encoded by GSB24 was similar to a salivary proline-rich glycoprotein precursor from rat. Three of the predicted extracellular proteins (SB4, SB59, and SB91) had significant homology with proteinases (SB4, lysosomal aspartic protease precursor from Necator americanus; SB59, cathepsin S-like cysteine proteinase from $H$. glycines; and SB91, cysteine proteinase from C. elegans). GSB23 was identical to a dorsal gland cell protein of unknown function cloned previously from $H$. glycines. Clone GSB6 was similar to a hypothetical protein from C. elegans.

Of the remaining 12 clones, the predicted proteins of four clones (GSB13, GSB18, SB26, and SB84) had no homology with known proteins in BLASTP (Table 1). Seven predicted proteins had significant homology with $C$. elegans proteins, of which six (GSB15, GSB17, GSB25, GSB26, SB93, and SB61) were predicted to be cytoplasmic and one (SB3) was predicted to be mitochondrial by PSORT II (Table 1). The predicted protein of clone SB76 had homology with histones from Emericella nidulans and C. elegans.

\section{DISCUSSION}

Secretory proteins encoded by parasitism genes expressed in the esophageal gland cells and secreted through the stylet represent the most advanced adaptation for plant parasitism by nematodes. These secretory proteins have a direct role in the infection and parasitism of plants, and temporal changes in the secretory proteins occur during the parasitic cycle (Davis et al. 2000). Direct molecular analysis of genes encoding secretory proteins expressed in the esophageal gland cells is critical to obtain a complete profile of parasitism genes expressed in the gland cells and to increase our understanding of the molecular interactions during nematode parasitism of plants. We combined the direct method of microaspirating the cytoplasm of the esophageal gland cells of $H$. glycines to provide expressed mRNA for RT-PCR with SSH to remove transcripts common to the intestinal region in order to construct a library enriched greatly in gland-cell cDNAs. Macroarraying the SSH cDNA library onto nylon membranes and high-throughput screening by in situ hybridization of selected clones resulted in the identification of 23 unique cDNA sequences, including four cDNA clones encoding putative parasitism genes expressed exclusively in the gland cells and predicted to be extracellular.

The predicted amino acid sequence of the full-length cDNA of GSB9 had strong similarity to the venom allergen antigen 5 family of secreted proteins from hymenopteran insect venom and proteins found in C. elegans and several animal-parasitic nematode species (Ding et al. 2000). In the animal-parasitic nematode Ancylostoma caninum, the AG-5-like proteins ACASP-1 and AC-ASP-2 are the major excretory-secretory proteins released by infective third-stage larvae stimulated to feed in vitro (Hawdon et al. 1996; Hawdon et al. 1999). The secretion of AC-ASP-1 and AC-ASP-2 is coupled with the transi- 
tion to parasitism and the invasion of the host by the larvae. Although the biological functions of venom allergen-like extracellular proteins in any nematode remain obscure, the in situ localization of GSB9 mRNA in the subventral gland cells of $H$. glycines may be indicative of a role for this protein in the interaction of this parasite with its host plant.
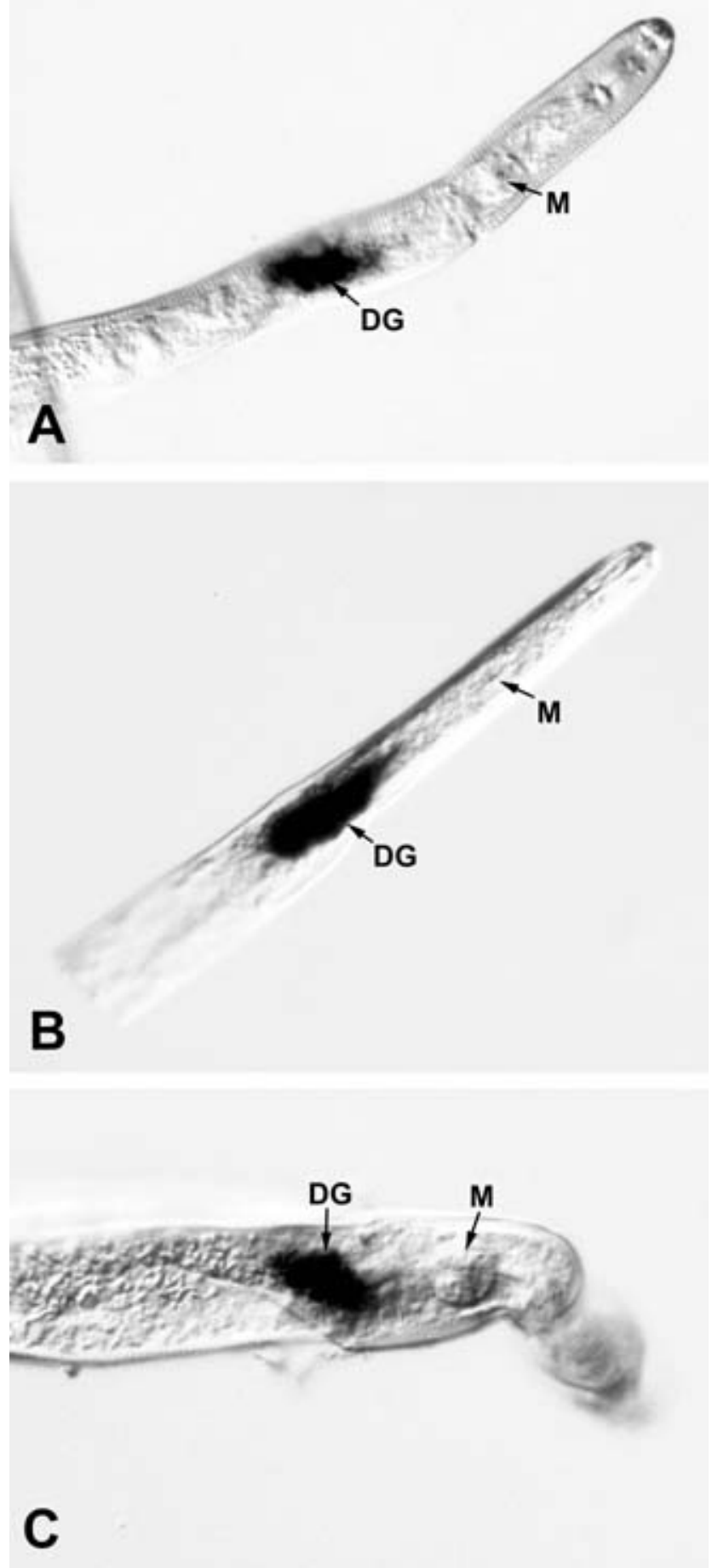

Fig. 3. Hybridization of a digoxigenin-labeled antisense cDNA probe (dark staining) of clone SB89 (Table 1) to transcripts expressed exclusively within the dorsal esophageal gland cell of Heterodera glycines. A, Preparasitic second-stage juvenile. B, Parasitic second-stage juvenile. C, Late parasitic stage. DG, dorsal gland.
The predicted protein for the full-length cDNA of GSB24 had strong similarity to salivary proline-rich glycoproteins from rat and human (Maeda et al. 1985; Miao et al. 1995). These extracellular proteins contain many proline-rich repeating peptides and, although present in saliva, their functions remain unknown. The localization of GSB24 mRNA exclusively in the dorsal gland cell, i.e., the gland cell presumably involved in the late stages of parasitism indicates that this protein may have a role in plant parasitism.

Of the other two cDNA clones (GSB23 and SB89) that encoded proteins with putative signal peptides and expressed specifically within the dorsal gland cell, GSB23 was cloned previously from the dorsal gland cell of the parasitic stages of $H$. glycines. Nevertheless, its function and any related proteins remain unknown (Wang et al. 2001). SB89, also predicted by PSORT II to be extracellular, had no significant matches with any proteins in the databases.

Clones SB4, SB59, and SB91, which had significant BLASTP similarities to proteinases, each encoded a protein preceded by a signal peptide and predicted by PSORT II to be extracellular. SB59 encodes a cathepsin S-like cysteine proteinase, hgcp-II, isolated previously from $H$. glycines (Urwin et al. 1997). The specific in situ localization of the expression of all three putative proteinase cDNA clones in intestinal cells suggests a digestive role for the encoded proteinases when they are secreted into the intestinal lumen. Indeed, such a role for proteinases has been suggested by the histochemical detection of cysteine proteinase activity within the intestine of feeding H. glycines females (Lilley et al. 1996).

The presence of a putative signal peptide alone is not conclusive proof that the encoded protein functions as an extracellular protein because membrane-associated proteins also have signal peptides. Of the six clones (GSB9, GSB23, GSB3, GSB21, GSB24, and SB89) that were predicted to encode signal peptides and were in situ localized in the dorsal or subventral gland cells of $H$. glycines, only four clones (GSB9, GSB23, GSB24, and SB89) were predicted to be extracellular by PSORT II analysis and thus should be considered to have roles in nematode parasitism. GSB3, however, was predicted by PSORT II analysis to be localized nuclearly but because the predicted encoded protein is preceded by a signal peptide for secretion, the GSB3 product might be a candidate for a nematode secretory protein that enters the plant nucleus if secreted into a parasitized root cell. This possibility makes GSB3 a prime candidate for further functional analyses. A further demonstration of a role for GSB3, GSB9, GSB23, GSB24, and SB89 products in

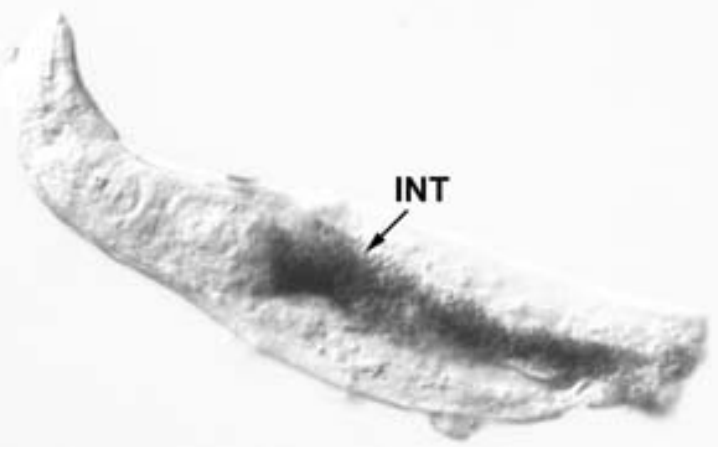

Fig. 4. Hybridization of a digoxigenin-labeled antisense cDNA probe (dark staining) of clone SB91 (Table 1) to transcripts expressed exclusively within the intestinal (INT) cells of Heterodera glycines. 
plant parasitism will require immunolocalization of the proteins in secretory granules in the nematode and their secretion by $H$. glycines in planta.

$\mathrm{SSH}$ is a PCR-based cDNA subtractive hybridization method that is used to selectively amplify differentially expressed cDNA fragments while simultaneously suppressing the amplification of nondifferentially expressed cDNAs (Diatchenko et al. 1996). SSH overcomes the problem of differences in mRNA abundance by incorporating a hybridization step that normalizes sequence abundance during the course of subtraction by standard hybridization kinetics. Common mRNAs (housekeeping and structural genes) and possible bacterial contamination in aspirated $H$. glycines gland cell cytoplasm can be subtracted by the aspirated intestinal region cDNAs generate under the same conditions at the same time as the gland cell cDNAs. Hypothetically, after three rounds of subtractive hybridization in the same set of samples, the remaining cDNAs should be expressed exclusively in the gland cells used as a tester. The problem of bacterial genes contaminating nematode cDNA libraries (Wang et al. 2001) was apparently eliminated by SSH because all of the 23 clones identified were nematode genes based on hybridization to $H$. glycines genomic DNA in Southern blots. Incomplete subtraction with intestinal cDNAs, however, did occur as the three proteinase clones were expressed in the intestine. The use of aspirated intestinal contents from only four nematodes as the driver probably contributed to this incomplete subtraction.

Constructing a gland-cell LD PCR cDNA library macroarray from the same gland cytoplasm used to construct the SSH cDNA library provided a powerful tool for isolating fulllength cDNAs of clones identified in the SSH cDNA library. Obtaining full-length cDNAs is a prerequisite for fully characterizing isolated cDNA clones. Full-length cDNAs provide the data to more reliably predict the identity of deduced proteins.

Characterizing the nature and number of different secretory proteins packaged in the secretory granules in nematode esophageal gland cells and the temporal changes in the kinds of proteins secreted during the parasitic cycle is a prerequisite for defining what makes a nematode a plant parasite. The procedure outlined herein provides a novel strategy to rapidly clone parasitism genes encoding these secretory proteins.

\section{MATERIALS AND METHODS}

\section{Nematode culture and collection.}

$H$. glycines and $M$. incognita were cultured on greenhousegrown soybean (Glycine max) and tomato (Lycopersicon esculentum cv. Rutgers), respectively. Preparasitic second-stage juveniles (J2) of both genera were collected by hatching eggs on sieves with $25-\mu \mathrm{m}$ openings suspended over deionized water in plastic bowls, as described previously (Ding et al. 1998). C. elegans were cultured on OP50 of Escherichia coli (Brenner 1974).

\section{Microaspiration of gland cells and intestinal region.}

Parasitic stages of $H$. glycines were hand dissected from infected soybean roots and placed into $1.5-\mathrm{ml}$ sterile tubes. Nematodes were washed three times with sterile water and placed on an agar $(0.5 \mathrm{ml}$ of sterile, warm $0.7 \%$ agarose $)$ pad on glass slides. Nematodes were covered with $40^{\circ} \mathrm{C}, 0.7 \%$ agarose and rapidly aligned vertically under the microscope before the agarose solidified. Micropipettes (aluminosilicate glass, optical density at $1.0 \mathrm{~mm}$, inside diameter of $0.68 \mathrm{~mm}$, and $10 \mathrm{~cm}$ in length) were pulled on a Model P-97 automated horizontal micropipette puller (Sutter Instrument, Novato, CA, U.S.A.). The 3- to 4- $\mu$ m-diameter tip opening was beveled at a $45^{\circ}$ angle with a Model BV-10 micropipette beveller (Sutter Instrument). Microaspirations were performed on a microinjection station comprising an Eclipse TE300 inverted microscope (Nikon, Tokyo, Japan) equipped with Nomarski differential-interference contrast and a Model 5171 micromanipulator (Eppendorf, Madison, WI, U.S.A.), a CellTram Oil 5176 microinjector-aspirator (Eppendorf), and a color video system with a DXC-107A camera and PVM-1353MD monitor (Sony Medical Systems, Montvale, NJ, U.S.A.). The contents (approximately $0.5 \mathrm{pl}$ ) of the esophageal gland cells or intestinal region of parasitic stages of $H$. glycines were aspirated into micropipettes containing $10.0 \mu \mathrm{l}$ of mRNA extraction buffer (100 mM Tris-HCl, pH 8.0; $500 \mathrm{mM} \mathrm{LiCl} ; 10 \mathrm{mM}$ EDTA, $\mathrm{pH}$ $8.0 ; 0.1 \% \mathrm{LiDS}$; and $5 \mathrm{mM}$ dithiothreitol [DTT]) to protect the cellular mRNA from RNase activity. Needle contents were transferred into separate microfuge tubes along with the needle tip and stored at $-80^{\circ} \mathrm{C}$ until used.

\section{Southern and virtual Northern hybridization.}

Genomic DNA was isolated from preparasitic $\mathrm{J} 2$ for $H$. glycines and $M$. incognita, mixed stages for $C$. elegans, and leaves for G. max and L. esculentum. Three hundred microliters of nematodes were frozen in 1.5-ml microcentrifuge tubes with liquid nitrogen and ground with a smooth-end metal bar. Frozen leaves (10 g) were pulverized in a mortar. Nematode genomic DNA was prepared as described by Ray et al. (1994), and plant genomic DNA was prepared according to Rogers and Bendich (1985). Genomic DNA was digested with EcoRI, and $10 \mu \mathrm{g}$ of nematode genomic DNA and $20 \mu \mathrm{g}$ of plant genomic DNA were used per lane for each Southern blot. The LD PCR amplification products of first-strand cDNAs from $H$. glycines gland cells and intestinal region were purified with the QIAquick PCR purification kit (Qiagen, Valencia, CA, U.S.A.) and used for "virtual Northern" analyses at $50 \mathrm{ng}$ per lane. This methodology gives information similar to that provided by standard Northern blots (Endege et al. 1999). Hybridization probes were made by amplifying cDNAs from original plasmids by PCR with nested PCR primers $1\left(5^{\prime}\right.$ TCGAGCGGCCGCCCGGGCAGGT-3') and 2R (5'-AGCGTGGTCGCGGCCGAGGT-3') (Clontech Laboratories, Palo Alto, CA, U.S.A.). PCR products were cut from gel, purified with the QIAquick gel extraction kit (Qiagen), and the RTS RadPrime DNA labeling system (GIBCO-BRL, Grand Island, NY, U.S.A.) was used to random prime label with ${ }^{32} \mathrm{P}-\mathrm{dCTP}$. Genomic DNA and amplified cDNA were transferred onto Hybond-N nylon membranes (Amersham Pharmacia Biotech, Piscataway, NJ, U.S.A.) from $1 \%$ agarose gels. High-stringency hybridization $\left(68^{\circ} \mathrm{C}\right.$ overnight) was performed according to standard procedures (Sambrook et al. 1989), and membranes were washed with $0.1 \times \mathrm{SSC}(1 \times \mathrm{SSC}$ is $0.15 \mathrm{M} \mathrm{NaCl}$ plus $0.015 \mathrm{M}$ sodium citrate), and $0.1 \%$ sodium dodecyl sulfate at $68^{\circ} \mathrm{C}$. Hyperfilm (Amersham Pharmacia Biotech) was developed after overnight exposure at $-80^{\circ} \mathrm{C}$.

\section{Gland cell and intestinal region cDNA amplification by LD PCR.}

Poly $(\mathrm{A})^{+}$RNA from the cytoplasm of gland cells aspirated from 10 parasitic nematodes or the contents from the intestinal regions of four nematodes was bound to $25 \mu \mathrm{g}$ of Dynabeads 
oligo(dT) ${ }^{25}$ magnetic beads (Dynal, Lake Success, NY, U.S.A.) and eluted with $5 \mu \mathrm{l}$ of diethyl pyrocarbonate (DEPC)-treated $\mathrm{d}_{2} \mathrm{H}_{2} \mathrm{O}$ at $70^{\circ} \mathrm{C}$ for $2 \mathrm{~min}$. The gland cell and intestinal region first-strand cDNA syntheses were carried out in $0.5-\mathrm{ml}$ reaction tubes in 10- $\mu \mathrm{l}$ volume of $4 \mu \mathrm{l}$ of mRNA sample, $0.5 \mu \mathrm{l}$ of $10 \mu \mathrm{M}$ cDNA synthesis primer (5'-AAGCAGTGGTAACAACGCAGAGTA-CT $\left.{ }_{(30)} \mathrm{N}_{-1} \mathrm{~N}-3^{\prime}\right)\left(\mathrm{N}_{-1}=\mathrm{A}, \mathrm{G}\right.$, or C) (N-3 = A, C, $\mathrm{G}$, or $\mathrm{T}$ ) (Clontech Laboratories), $0.5 \mu \mathrm{l}$ of $10 \mu \mathrm{M}$ SMART II oligonucleotide (5'-AAGCAGTGGTAA-CAACGCAGAGTACGCGGG-3') (Clontech Laboratories), $2.0 \mu \mathrm{l}$ of $5 \times$ first-strand buffer, $1.0 \mu \mathrm{l}$ of $20 \mathrm{mM}$ DTT, $1.0 \mu \mathrm{l}$ of $10 \mathrm{mM} 50 \times \mathrm{dNTP}, 1.0 \mu \mathrm{l}$ of Superscript II (200 units per $\mu$ ) (GIBCO-BRL). The tubes were incubated at $42^{\circ} \mathrm{C}$ for $1 \mathrm{~h}$, and $90 \mu \mathrm{l}$ of TE buffer $(10 \mathrm{mM}$ Tris, $\mathrm{pH}$ 7.6; and $1 \mathrm{mM}$ EDTA) was added. Ten microliters of diluted first-strand reaction solution, $2 \mu \mathrm{l}$ of $10 \mathrm{mM}$ dNTP mix, $10 \mu$ of Taq Plus Long $10 \times$ low-salt buffer (Stratagene, La Jolla, CA, U.S.A.), $1 \mu \mathrm{l}$ of Taq Plus Long, $2 \mu \mathrm{l}$ of PCR primer (5'AAGCAGTGGTAACAA-CGCAGAGT-3') (Clontech Laboratories) were used in 100- $\mu$ l volume of LD PCR reaction. LD PCR was performed with hot-start, followed by 24 cycles at $94^{\circ} \mathrm{C}(20 \mathrm{~s}), 65^{\circ} \mathrm{C}(30 \mathrm{~s})$, and $72^{\circ} \mathrm{C}(7 \mathrm{~min})$. Negative water controls were performed at each appropriate step.

\section{Suppression subtractive hybridization.}

For the gland cells and intestinal region, $300 \mu \mathrm{l}$ of LD PCR product was extracted with phenol-chloroform-isoamyl alcohol (25:24:1), followed by n-butanol. cDNAs in aqueous phase were size selected by passing through a CHROMA APIN-1000 DEPC- $\mathrm{H}_{2} \mathrm{O}$ column (Clontech Laboratories). The doublestranded cDNA fractions were digested with $R s a \mathrm{I}$ to obtain shorter, blunt-ended molecules, then purified with the NucleTrap PCR kit according to manufacturer's instructions (Clontech Laboratories). The purified $R s a \mathrm{I}$-digested cDNA was precipitated by $4 \mathrm{M}$ ammonium acetate and absolute ethanol. The cDNA pellet was washed in $80 \%$ ethanol and dissolved in $15 \mu \mathrm{l}$ of TNE buffer (10 mM Tric-Cl; $150 \mathrm{mM} \mathrm{NaCl}$; and $1 \mathrm{mM}$ EDTA, pH 7.4) to obtain cDNA at a concentration of $300 \mathrm{ng}$ per $\mu \mathrm{l}$. A total of $4.5 \mu \mathrm{g}$ of purified RsaI-digested cDNA from gland cells and intestinal region each were prepared. SSH was performed with the PCR-Select cDNA subtraction kit (Clontech Laboratories), following the manufacturer's instructions with minor modifications (Diatchenko et al. 1996). The subtraction used cDNA fragments generated from the mRNA of gland cells as tester and fragments generated from the mRNA of the intestinal region as driver. For the subtraction, two tester populations were created by ligating two different adaptors, 1 and $2 \mathrm{R}$, onto the tester cDNA fragments. No adaptor was ligated to driver cDNA. In the first hybridization, $450 \mathrm{ng}$ of driver cDNA was mixed with 18 ng of tester cDNA (1:50). The reactions were denatured and allowed to anneal. In the second hybridization, the tester-driver mixtures were hybridized with additional $300 \mathrm{ng}$ of denatured driver cDNA added into the first hybridization pool. This step was followed by a primary PCR with PCR primer 1 and 35 cycles. Finally, differentially expressed cDNAs were amplified selectively by hot-start PCR with nested PCR primers 1 and $2 \mathrm{R}$ in the SSH kit.

\section{Construction of SSH}

\section{and gland cell LD PCR cDNA libraries.}

The SSH cDNA library was constructed by ligating the subtracted cDNA into pGEM-T vector (Promega, Madison, WI, U.S.A.). Similarly, the LD PCR amplification product derived from first-strand gland cell cDNA was used to generate the gland-cell LD PCR cDNA library except that pGEM-T Easy vector (Promega) was used. Ligation products were precipitated with $10 \mathrm{mM}$ glycogen and $100 \%$ ethanol, followed by a wash with $70 \%$ ethanol. Both sources of cDNA were purified with the QIAquick PCR purification kit prior to ligation. Ligations were carried out at a mass ratio of 3:1 (plasmid-cDNA) at $4{ }^{\circ} \mathrm{C}$ overnight. The purified ligation products were then electroporated into E. coli DH10B-competent cells. The efficiency of the electroporation for both libraries was $10^{8}$ clones per $\mu \mathrm{g}$ of vector. SpeI and $s p h \mathrm{I}$ were used to check the inserts in the pGEM-T vector, whereas EcoRI digestions were used for the pGEM-T Easy vector. Three-thousand white colonies (on blue-white selection) of the SSH cDNA library were hand picked and transferred to 96-well MICROTEST III tissue culture plates (Becton Dickinson, Franklin Lakes, NJ, U.S.A.), which contained $200 \mu \mathrm{l}$ of $10 \%$ glycerol Luria-Bertani with ampicillin. Plates were incubated overnight at $37^{\circ} \mathrm{C}$. This library was macroarrayed with BioGrid (BioRobotics, Malden, MA, U.S.A.) onto sterile Hybond-XL nylon membranes $(70 \times$ $105 \mathrm{~mm}$; Amersham Pharmacia Biotech). White colonies $(6,130)$ of the gland-cell LD PCR cDNA library were hand picked and printed on membranes by the same method.

\section{In situ and Southern hybridization screening of gland-specific cDNAs from the SSH cDNA library.}

To initially screen the SSH cDNA library, 20 clones were randomly selected and nested primers 1 and $2 \mathrm{R}$ were used to amplify the cDNAs in the plasmids. The PCR products were used to synthesize DIG-labeled sense and antisense cDNA probes by asymmetric PCR amplification with nested primers 1 and $2 \mathrm{R}$ as forward or reverse primers. Both PCR reactions were performed in a $20-\mu$ reaction mixture with the PCR digoxigenin (DIG)-labeling mix (Boehringer Mannheim, Mannheim, Germany) in the asymmetric PCR instead of dNTP in the normal PCR. In situ hybridization was performed as described by De Boer et al. (1998) but modified for highthroughput in situ screening. Mixed stages of parasitic $H$. glycines, collected 8 days after inoculation by root blending and sieving (De Boer et al. 1999), were washed three times with $1 \times$ phosphate-buffered saline buffer and fixed in $10 \%$ formalin buffered in phosphate ( $\mathrm{pH}$ 7.4) for 2 days at room temperature. The fixed nematodes were cut randomly on glass slides with a razor blade until approximately $90 \%$ of the nematodes were cut. Nematode sections were digested partially with $500 \mathrm{ng}$ per $\mathrm{ml}$ of proteinase-K (Boehringer Mannheim) at room temperature for $1 \mathrm{~h}$. After prehybridization, nematode sections in hybridization solution were aliquoted to wells of a 96-well MultiScreen plate (\#MAGVN2250; Millipore, Bedford, MA, U.S.A.). Denatured PCR DIG-labeled DNA probes $(1 \mu \mathrm{l})$ were added to each well. The Millipore MultiScreen vacuum manifold was used to change solutions by aspiration. cDNA probes that hybridized within the nematode sections were detected as described previously (De Boer et al. 1998). cDNAs that hybridized only to esophageal gland cells were sequenced and used to screen the gland-cell LD PCR library to obtain fulllength cDNAs. For subsequent screening of the SSH cDNA library, cDNAs used previously in screening were purified by gel extraction and $20 \mathrm{ng}$ of cDNAs were labeled with $\left[\alpha^{32} \mathrm{P}\right] \mathrm{dCTP}$ in one labeling reaction. The mixed probes were hybridized to a macroarray membrane of the SSH cDNA library, and the 
positive spots were marked. cDNAs that did not hybridize were selected randomly and used for in situ hybridization as before. For the final screening of the SSH cDNA library, 100 clones that did not hybridize to pooled probes from the previous screenings were selected for sequencing and new cDNA sequences were tested by in situ hybridization.

\section{cDNA sequencing and sequence alignments.}

Sequencing reactions were prepared from cDNA fragments that were positive in in situ hybridization as well as from full-length cDNAs isolated from the gland-cell, full-length library with $\mathrm{T} 7$ or SP6 primer and a cycle sequencing kit (Applied Biosystems, Foster City, CA, U.S.A.). Sequences were collected on an ABI377 autosequencer (Applied Biosystems). The predicted protein sequences from all cDNAs were analyzed based on a BLASTP search against the DDBJ/EMBL/GenBank databases. Sequences that did not show significant similarity to any of these entries were designated as pioneers. Signal peptide analysis was conducted on the cDNA-deduced protein sequences in Signal P (Nielsen et al. 1997). Subcellular localization of the deduced protein was predicted by PSORTII computer analysis (Nakai and Horton 1999).

\section{ACKNOWLEDGMENTS}

Support for this research was provided by the United Soybean Board (project 9214), Iowa Soybean Promotion Board, Iowa Agriculture and Home Economics Experiment Station (J-19320; project 3381), Hatch Act and State of Iowa, and the state and Hatch funds allocated to the Georgia Agricultural Experiments.

\section{LITERATURE CITED}

Brenner, S. 1974. The genetics of the nematode Caenorhabditis elegans. Genetics 77:71-94.

Davis, E. L., Hussey, R. S., Baum, T. J., Bakker, J., Schots, A., Rosso, M.-N. and Abad, P. 2000. Nematode parasitism genes. Annu. Rev. Phytopathol. 38:365-396.

De Boer, J. M., Yan, Y., Smant, G., Davis, E. L., and Baum, T. J. 1998. In-situ hybridization to messenger RNA in Heterodera glycines. J. Nematol. 30:309-312.

De Boer, J. M., Yan, Y., Wang, X., Smant, G., Hussey, R. S., Davis, E. L., and Baum, T. J. 1999. Developmental expression of secretory $\beta$ 1,4-endoglucanases in the subventral esophageal glands of Heterodera glycines. Mol. Plant-Microbe Interact. 12:663-669.

Diatchenko, L., Lau, Y.-F. C., Campbell, A. P., Chenchik, A., Moqadam, F., Huang, B., Lukyanov, S., Lukyanov, K., Gurskaya, N., Sverdlov, E. D., and Siebert, P. D. 1996. Suppression subtractive hybridization: A method for generating differentially regulated tissue-specific cDNA probes and libraries. Proc. Natl. Acad. Sci. USA 93:6025-6030.

Ding, X., Shields, J., Allen, R., and Hussey, R. S. 1998. A secretory cellulose-binding protein cDNA cloned from the root-knot nematode (Meloidogyne incognita). Mol. Plant-Microbe Interact. 11:952-959.

Ding, X., Shields, J., Allen, R. and Hussey, R. S. 2000. Molecular cloning and characterization of a venom allergen AG5-like cDNA from Meloidogyne incognita. Int. J. Parasitol. 30:77-81.

Endege, W. O., Steinmann, K. E., Boardman, L. A., Thibodeau, S. N. and Schlegel, R. 1999. Representative cDNA libraries and their utility in gene expression profiling. Biotechniques 26:542-550.

Goellner, M., Smant, G., De Boer, J. M., Baum, T., and Davis, E. L. 2000. Isolation of $\beta$-1,4-endoglucanase genes Globodera tabacum and their expression during parasitism. J. Nematol. 32:154-165.

Hawdon, J. M., Jones, B. F., Hoffman, D. R., and Hotez, P. J. 1996. Cloning and characterization of Ancylostoma-secreted protein. J. Biol. Chem. 271:6672-6678.

Hawdon, J. M., Narasimhan, S., and Hotez, P. J. 1999. Ancylostoma secreted protein 2: Cloning and characterization of a second member of a family of nematode secreted proteins from Ancylostoma caninum. Mol. Biochem. Parasitol. 99:149-166.
Hussey, R. S. 1989. Disease-inducing secretions of plant-parasitic nematodes. Annu. Rev. Phytopathol. 27:123-141.

Hussey, R. S., and Grundler, F. M. 1998. Nematode parasitism of plants. Pages 213-243 in: Physiology and Biochemistry of Free-Living and Plant Parasitic Nematodes. R. N. Perry and D. J. Wright, eds. CAB International Press, Wallingford, Oxfordshire, U.K.

Lambert, K. N., Allen, K. D., and Sussex, I. M. 1999. Cloning and characterization of a esophageal-gland-specific chorismate mutase from the phytoparasitic nematode Meloidogyne javanica. Mol. PlantMicrobe Interact. 12:328-336.

Lilley, C. J., Urwin, P. E., McPherson, M. J., and Atkinson, H. J. 1996. Characterization of intestinally active cysteine proteinases of cyst nematodes. Parasitology 113:415-424.

Maeda, N., Kim, H. S., Azen, E. A., and Smithies, O. 1985. Differential RNA splicing and post-translational cleavages in the human salivary proline-rich protein gene system. J. Biol. Chem. 260:11123-11130.

Miao, Y. J., Subramaniam, N., and Carlson, D. M. 1995. cDNA cloning and characterization of rat salivary glycoproteins. Novel members of the proline-rich-protein multigene families. Eur. J. Biochem. 228:343-350.

Nakai, K., and Horton, P. 1999. PSORT: A program for detecting sorting signals in proteins and predicting their subcellular localization. Trends Biochem. Sci. 24:34-35.

Nielsen, H., Engelbrecht, J., Brunak, S., and Von Heijne, G. 1997. Identification of prokaryotic and eukaryotic signal peptides and prediction of their cleavage sites. Protein Eng. 10:1-6.

Popeijus, H., Overmars, H., Jones, J., Blok, V., Goverse, Helder, J., Schots, A., Bakker, J., and Smant, G. 2000. Degradation of plant cell walls by a nematode. Nature 406:36-37.

Qin, L., Overmars, H., Helder, J., Popeijus, H., Van der Voort, J. R., Groenink, W., Van Koert, P., Schots, A., Bakker, J., and Smant, G. 2000. An efficient cDNA-AFLP-based strategy for the identification of putative pathogenicity factors from the potato cyst nematode Globodera rostochiensis. Mol. Plant-Microbe Interact. 13:830-836.

Ray, C., Abbott, A. G., and Hussey, R. S. 1994. Trans-splicing of a Meloidogyne incognita mRNA encoding a putative esophageal gland protein. Mol. Biochem. Parasitol. 68:93-101.

Rogers, S. O., and Bendich, A. J. 1985. Extraction of DNA from milligram amounts of fresh, herbarium and mummified plant tissues. Plant Mol. Biol. 5:69-76.

Rosso, M.-N., Favery, B., Piotte, C., Arthaud, L., De Boer, J. M., Hussey, R. S., Bakker, J., Baum, T. J., and Abad, P. 1999. Isolation of a cDNA encoding a $\beta$-1,4-endoglucanase in the root-knot nematode Meloidogyne incognita and expression analysis during plant parasitism. Mol. Plant-Microbe Interact.12:585-591.

Sambrook, J., Fritsch, E. F., Maniatis, T. 1989. Molecular Cloning: A Laboratory Manual, 2nd ed. Cold Spring Harbor Laboratory, Cold Spring Harbor, NY, U.S.A.

Smant, G., Stokkermans, J. P. W. G., Yan, Y., De Boer, J. M., Baum, T. J., Wang, X., Hussey, R. S., Gommers, F. J., Henrissat, B., Davis, E. L., Helder, J., Shots, A., and Bakker, J. 1998. Endogenous cellulases in animals: Isolation of $\beta$-1,4-endoglucanase genes from two species of plantparasitic cyst nematodes. Proc. Natl. Acad. Sci. USA 95:4906-49011.

Tweedie, S., Paxton, W. A., Ingram, L., Maizels, R. M., McReynolds, L. A., and Selkirk, M. E. 1993. Brugia pahangi and Brugia malayi: A surface-associated glycoprotein (gp 15/400) is composed of multiple tandemly repeated units and processed from a 400-kDa precursor. Exp. Parasitol. 76:156-164.

Urwin, P. E., Lilley, C. J., McPherson, M. J., and Atkinson, H. J. 1997. Characterization of two cDNAs encoding cysteine proteinases from the soybean cyst nematode Heterodera glycines. Parasitology 114:605-613.

Wang, X., Meyers, D., Yan, Y., Baum, T., Smant, G., Hussey, R., and Davis, E. 1999. In planta localization of a $\beta$-1,4-endoglucanase secreted by Heterodera glycines. Mol. Plant-Microbe Interact 12:64-67.

Wang, X., Allen, R., Ding, X., Goellner, M., Maier, T., De Boer, J. M., Baum, T. J., Hussey, R. S., and Davis, E. L. 2001. Signal peptide-selection of cDNA cloned directly from the esophageal gland cells of the soybean cyst nematode Heterodera glycines. Mol. Plant-Microbe Interact. 14:536-544.

Yan, Y., Smant, G., Stokkermans, J., Qin, L., Helder, J., Baum, T., Schots, A., and Davis, E. 1998. Genomic organization of four $\beta-1,4-$ endoglucanase genes in plant-parasitic cyst nematodes and its evolutionary implications. Gene 220:61-70. 